\title{
BSA and molecular markers screening for salt stress tolerant mutant of Petunia obtained in in vitro culture
}

\author{
Marcelina Krupa-Małkiewicz $^{1^{*}} \odot$ Anna Bienias ${ }^{1}$ \\ ${ }^{1}$ Department of Plant Genetics, Breeding and Biotechnology, West Pomeranian University of Technology, Szczecin (ZUT), Słowackiego str.17, \\ 71-434 Szczecin, Poland. E-mail: mkrupa@zut.edu.pl. ${ }^{*}$ Corresponding author.
}

ABSTRACT: In this study, we performed BSA to identify genetic markers linked to salt tolerance. We tested the genetic diversity among four bulked DNA samples of EMS induced mutant clones and one bulked DNA sample of non-mutated clone of Petunia for salt tolerance in in vitro callus cultures using RAPD and ISSR markers. Out of the 36 RAPD and 16 ISSR primers identified, 25 and 13 were effectively used to amplify genomic DNA of all the five bulked samples, respectively. In total, 114 RAPD amplifications products were obtained, of which 28\% were polymorphic and 2\% were genotype-specific bands. Out of the 64 ISSR amplification products obtained, 51\% were polymorphic and 1\% was genotype-specific bands. Results of this study indicated the existence of two patterns of distorted segregation among the studied markers. The first one indicates the differences between non-mutated clones of Petunia and its putative mutants. The second one was observed only between putative mutants and putative mutants tested for salt tolerance in in vitro culture. Both RAPD and ISSR analysis successfully detected the association with changes induced by chemical mutagenesis and salinity. Furthermore, our results indicate that BSA method can be useful in the rapid detection of molecular markers for further marker-assisted selection.

Key words: bulk segregant analysis, chemical mutagenesis, ISSR, RAPD, Petunia $\times$ atkinsiana D. Don, salt stress, tissue culture.

Rastreamento de BSA e marcadores moleculares para mutante tolerante ao estresse salino de Petunia obtido em cultura in vitro

RESUMO: Neste estudo, realizamos BSA para identificar marcadores genéticos ligados à tolerância ao sal. Testamos a diversidade genética entre quatro amostras de DNA volumoso de clones mutantes induzidos por EMS, e uma amostra de DNA volumoso de clone não mutado de Petunia para tolerância a sal em culturas de calos in vitro usando marcadores RAPD e ISSR. Dos 36 primers RAPD e 16 ISSR identificados, 25 e 13 foram efetivamente usados para amplificar o DNA genomico de todas as cinco amostras, respectivamente. No total, foram obtidos 114 produtos de amplificação RAPD, dos quais 28\% eram polimórficos e 2\% eram bandas especificas de genótipos. Dos 64 produtos de amplificação ISSR obtidos, $51 \%$ eram polimórficos e $1 \%$ eram bandas especificas de genótipo. Os resultados deste estudo indicam a existência de dois padrões de segregação distorcida entre os marcadores estudados. O primeiro indica as diferenças entre os clones não mutantes de Petúnia e seus mutantes putativos. O segundo foi observado apenas entre mutantes putativos e mutantes putativos testados quanto à tolerância ao sal em cultura in vitro. Tanto a análise RAPD quanto a ISSR detectaram com sucesso a associação com alterações induzidas por mutagênese química e salinidade. Além disso, nossos resultados indicam que o método BSA pode ser útil na detecção rápida de marcadores moleculares para posterior seleção assistida por marcadores.

Palavras-chave: análise segregante a granel, mutagênese química, ISSR, RAPD, Petúnia $\times$ atkinsiana D. Don, estresse salino, cultura de tecidos.

\section{INTRODUCTION}

Salinity is one of the abiotic factors that influences growth and vigor of many crops. However, exposure of crops to high salinity and other than abiotic stress factors such as drought, temperature, chemical toxicity, and so on affects its production. Nearly $20 \%$ of the cultivated land and about half of the irrigated land are affected by high salinity (PATADE et al., 2006). Therefore, high priority is warranted in breeding programs, which aim salinity tolerant crops (BIDABADI et al., 2011). Tolerance of high salinity of many agricultural crops has been reported (SHALABY \& EL-BANNA, 2013). However, floriculture breeding program are not actively selecting new cultivars for salt tolerance. The most effective means that can deal with soil salinity is to grow cultivars that can establish and be productive on such soil (MIRI et al., 2014). Petunia $\times$ atkinsiana D. Don. belongs to Solanaceae family and is often considered a secondary plant model-system, due to various favorable biological features. Cultivar Prism Red has large flowers and made heavy texture largely produced for home-consumption and for gardening (VANDENBUSSCHE et al., 2006; BERENSCHOT et al., 2008). Due to the important 
role of the Solanaceae family in agronomic and ornamental crops, salt tolerance in this family was examined. Salt tolerant plants can be derived through somaclonal variation with induced mutations. To maintain high productivity under adverse growing conditions, many breeders search for more tolerant forms using traditional breeding approach or artificial selection; although, much emphasis is currently being laid on molecular techniques. To achieve this researchers aim to obtain crops that demonstrate an increased tolerance to salt stress or drought using in vitro cultures from inter alia, banana (BIDABADI et al., 2011), potatoes (GOPAL \& IWAMA, 2007), sweet potatoes (LUAN et al., 2007), cauliflower (FULLER et al., 2006). Usually, somaclonal variation with or without chemical or physical mutagenesis is used as a source of plants' new genotype for crop improvement (BAGHWAT \& DUNCAN, 1998; JAIN, 2000; BAIRU et al., 2011; MIRI et al., 2014). However, a combination of somaclonal variability along with mutagenesis induced in in vitro cultures may considerably increase the level of variability in the resultant variants that may impart increase tolerance to environmental stress factor. However, several variants derived by this method can be either unstable or non-heritable because of the epigenetic changes in the resultant crop rather than the genetic changes. To make the collection useful for breeders, morphological and molecular characterization of the germplasms is necessary. Application of molecular tools can provide new approaches to increase the salt tolerance of many crops and horticultural species. Genes associated with salt tolerance have been identified in model plants, like Arabidopsis (YOKOI et al., 2002). Detailed knowledge of genome and transcription for most floricultural species is not yet available. Therefore, information about the genes involved, collected from other species, might be used as, markers in order to accelerate the selection process for this property (MUNNS, 2005).

Bulked segregant analysis (BSA) is a method that can be used for the rapid screening and verification of useful molecular markers during the selection and breeding process. It can be used to identify individual markers associated with a specific phenotype. BSA can efficiently and rapidly identify genetic markers associated with a particular trait (MASOJĆ et al., 2009). In addition to BSA, random amplified polymorphic DNA(RAPD) and inter simple sequences repeat (ISSR) markers used in this study provide greater opportunities in determining the exact relationship between a specific DNA sequence and the examined trait and also in determining the exact relationship between a specific DNA sequence and the examined trait and also in determining a plant's identity using particular genes. Both of these methods are popular DNA fingerprinting methods because they are inexpensive, highly polymorphic, quick and easy to perform.

In this study, we tested genetic diversity among four bulked DNA samples of ethyl methanesulphonate (EMS)-induced mutant clones and one bulked DNA sample of non-mutated clone of Petunia $\times$ atkinsiana D. Don. cv. Prism Red to identify genetic markers linked to salt tolerance in in vitro callus cultures using RAPD and ISSR markers.

\section{MATERIALS AND METHODS}

\section{Plant material}

The samples used in this study were leaves of Petunia $\times$ atkinsiana D. Don cv. Prism Red. Clones were obtained from callus culture, treated by $0.5 \mathrm{mM}$ EMS and screening for salt tolerance using 50, 100 and $150 \mathrm{mM} \mathrm{NaCl}$ in in vitro culture (KRUPAMAŁKIEWICZ et al., 2017). Genetics analysis based on molecular markers using BSA method in bulked samples as follows: (1) control plants derived from callus not treated with chemical mutagen; (2) plants derived from callus treated with $0.5 \mathrm{mM}$ EMS; (3) plants derived from callus treated with $0.5 \mathrm{mM}$ EMS and cultured on MS medium (MURASHIGE \& SKOOG, 1962) supplemented with $50 \mathrm{mM} \mathrm{NaCl}$; (4) plants derived from callus treated with $0.5 \mathrm{mM}$ EMS and cultured on MS medium supplemented with $100 \mathrm{mM} \mathrm{NaCl}$; and (5) plants derived from callus treated by $0.5 \mathrm{mM}$ EMS and cultured on MS medium supplemented with $150 \mathrm{mM} \mathrm{NaCl}$. Each bulk contained 12 individual samples selected to have identical phenotypes and increased reaction to salt stress. Explants that did not indicate tolerance to salt stress were dying out and were not taken for further research, due to the lack of a sufficient amount of plant material. Bulks were prepared by mixing equal proportions of DNA from each individual in each bulk. All bulks were subjected to genetic analysis using RAPD and ISSR techniques to search for differentiating polymorphisms. Only DNA fragments that differentiated between the control bulk and putative mutants' bulk were considered mutation linked markers.

\section{Plant DNA extraction}

Total genomic DNA was isolated separately from lyophilized leaves $(20 \mathrm{mg})$ of Petunia $\times$ atkinsiana D. Don in $-56^{\circ} \mathrm{C}$ using the standard 
protocol of DNeasy Plant Mini Kit (Qiagen). Qualitative and quantitative DNA isolates were made using a spectophotometr Epoch (BioTek) by spectroscopy method UV-Vis and visually checked on $1 \%$ agarose gel.

\section{RAPD amplification}

PCR amplification was carrying out with a set of 36 oligonucleotides, arbitrary primers (Biomers) according to the method described by WILLIAMS et al. (1990). The PCR-RAPD reaction and temperature profiles of each step were optimized and standardized to laboratory condition and type of chemical reagents, especially polymerase used in this study. Modifications included amount of polymerase, number of reaction cycles, annealing temperature and elongation time to ensure optimal conditions and obtain stable and reproducible amplification products. Amplifications were performed in $15 \mu \mathrm{l}$ reaction volume containing $10 \times \mathrm{PCR}$ buffer with $\left(\mathrm{NH}_{4}\right)_{2} \mathrm{SO}_{4}$, $2.0 \mathrm{mM}$ of dNTPs, $2.0 \mathrm{mM} \mathrm{MgCl}, 0.5 \mu \mathrm{M}$ of primer, 1.0U Taq DNA polymerase (Thermo Scientific) and $\sim 10 \mathrm{ng} / \mu \mathrm{l}$ of template DNA. Amplifications were carried out in DNA Engine Dyad ${ }^{\circledR}$ Thermal Cycler (Biorad). According to thermal program: initial denaturation step at $94^{\circ} \mathrm{C}$ for $3 \mathrm{~min}, 10$ cycles - denaturation $94^{\circ} \mathrm{C} 1 \mathrm{~min}$, annealing $-37^{\circ} \mathrm{C}$ $30 \mathrm{~s}$, elongation $72^{\circ} \mathrm{C} 30 \mathrm{~s}, 35$ cycles $-94^{\circ} \mathrm{C} 1 \mathrm{~min}$, annealing $37^{\circ} \mathrm{C} 30 \mathrm{~s}$, elongation $72^{\circ} \mathrm{C} 1 \mathrm{~min}$ with final extension step at $72^{\circ} \mathrm{C} 5 \mathrm{~min}$.

\section{ISSR amplification}

PCR reactions were carried out in a total volume of $25 \mu \mathrm{l}$ containing $50 \mathrm{ng}$ of template DNA, 1U Taq DNA polymerase (Thermo Scientific), $2.5 \mu 1$ $10 \times$ PCR buffer, $2.0 \mathrm{mM}$ dNTP and $2.0 \mathrm{mM} \mathrm{MgCl}_{2} .16$ primers (Metabion, Germany) were used for the PCR. DNA was amplified using a DNA Engine Dyad ${ }^{\circledR}$ Thermal Cycler (Biorad) and using the following program: initial denaturation at $95^{\circ} \mathrm{C}$ for $3 \mathrm{~min}, 35$ cycles - denaturation $30 \mathrm{~s}$ at $95^{\circ} \mathrm{C}$, annealing $30 \mathrm{~s}$ at optimal temperature, elongation $2 \mathrm{~min}$ at $72^{\circ} \mathrm{C}$, and $5 \mathrm{~min}$ at $72^{\circ} \mathrm{C}$ for final extension. The annealing temperature was usually adjusted according to the $\mathrm{T}_{\mathrm{m}}$ of the primers being used in the reaction. The products were held at $4^{\circ} \mathrm{C}$ until analyzed.

\section{Electrophoresis and data analysis}

PCR products were mixed with $6 \times$ Loading Dye Solution and were analyzed by electrophoresis on $1.5 \%$ agarose gel (Basica LE-Prona) at $8 \mathrm{~V} / \mathrm{cm}$ for 110 min (in $1 \times \mathrm{TBE}$ buffer). DNA Gene Ruler 100 bp ladder (Fermentas) was used as a size markers.
PCR products were stained with ethidium bromide $(0.1 \mathrm{mg} / \mathrm{ml})$ under UV light in a Syngene C:Box using GeneSnap Software. The RAPD and ISSR bands were scored as a present (1) or absent (0), each of which was treated as an independent characters regardless of its intensity.

\section{RESULTS}

Genome screening using RAPD and ISSR analysis revealed genetic polymorphism between the bulked DNA samples of Petunia $\times$ atkinsiana D. Don cv. Prism Red treated with mutagen from the control bulk samples. Two types of segregation patterns in the markers were observed in this study. First polymorphism was observed in control bulk and bulks from the explants treated with chemical mutagen (EMS) (Figure 1). The second polymorphism differentiated within putative mutants of Petunia and putative mutants tested for salt stress (Figure 1).

\section{RAPD analysis}

Of the 36 RAPD primers initially screened, 25 were effectively used to amplify genomic DNA of all five bulked samples. Length of bands varied from 380 to $1820 \mathrm{bp}$ in size. On an average, each primer produced four bands. In total, 114 RAPD products were obtained, of which $64(65 \%)$ were monomorphic, 41 (28\%) were polymorphic, and 9 (2\%) - genotype-specific bands (Table 1). The primer pr29 produced the maximum number of bands (nine bands), of which four were polymorphic bands. Only five primers (pr879, pr611, pr110, pr310 and pr483) generated monomorphic bands. The RAPD profile of the selected putative mutant, putative mutants tested for salinity and lines from the control plants revealed genetic polymorphism. The pr539, pr429 and pr797 primers generated four polymorphic bands characteristic only for all EMS putative mutants and three (pr88, pr1100 and 1049) were only for the control (Table 2). In this study, we recorded an interesting observation in case of RAPD profile obtained from sixteen primers (pr176, pr269, pr447, pr598, pr29, pr66, pr88, pr99, pr107, pr139. pr815, pr875, pr144, pr519, pr920, pr1049); we obtained specific bands only for EMS putative mutants tested for salt tolerance (Table 2).

\section{ISSR analysis}

Five bulked samples were fingerprinted using 13 of the 16 ISSR primers generating 64 amplicons ranging from 410 to $1560 \mathrm{bp}$. Of these, $23(45 \%)$ were monomorphic and $38(51 \%)$ were 

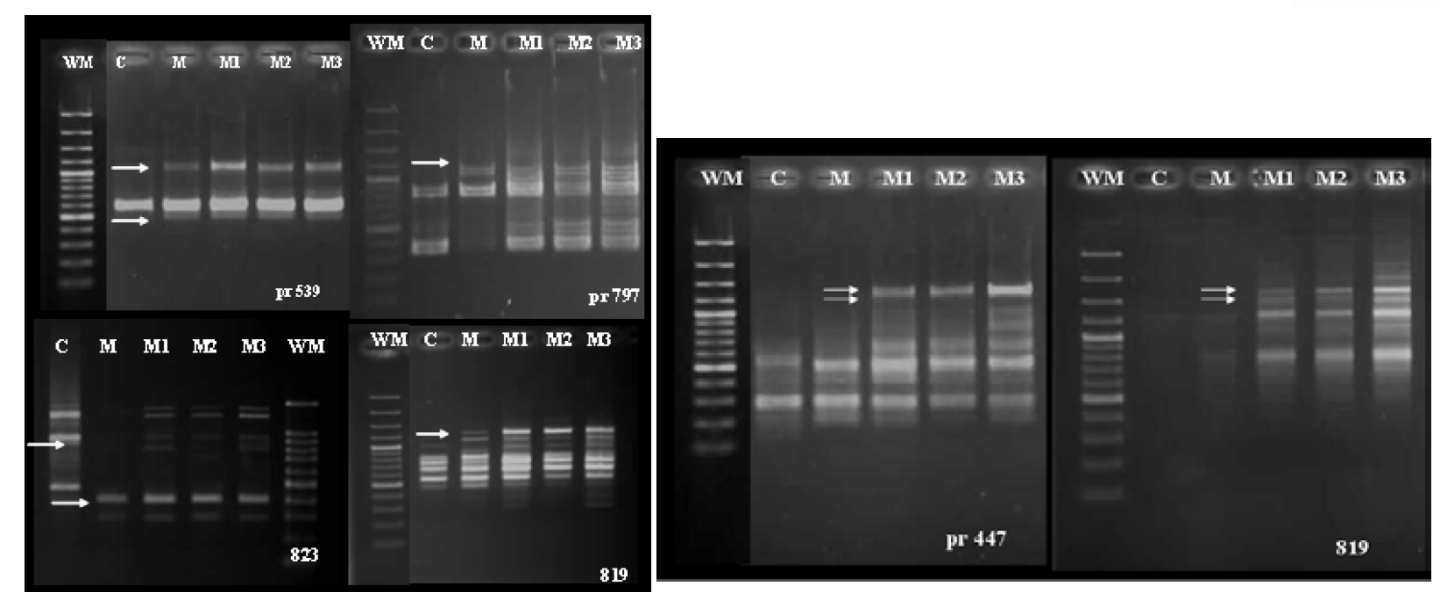

WM - weight mass DNA Gene Ruler

C - Control

Figure 1 - RAPD (pr539, pr797) and ISSR $(823,819)$ profiles generated by different primers obtained from EMS treated variants $(\mathrm{M})$ and variants selected on $\mathrm{MS}$ medium with $50 \mathrm{mM} \mathrm{NaCl}(\mathrm{M} 1), 100 \mathrm{mM} \mathrm{NaCl}(\mathrm{M} 2)$ and $150 \mathrm{mM} \mathrm{NaCl}$ (M3) of Petunia (left), and RAPD (pr447) and ISSR (819) profiles generated by different primers obtained from $0.5 \mathrm{mM}$ EMS treated variants selected on MS medium with $50 \mathrm{mM} \mathrm{NaCl}(\mathrm{M} 1), 100 \mathrm{mM} \mathrm{NaCl}(\mathrm{M} 2)$ and $150 \mathrm{mM}$ $\mathrm{NaCl}$ (M3) of Petunia (right). Arrows show different amplification in each regenerated variant.

polymorphic bands (Table 1). On an average, each primer produced five bands. More number of bands (eight bands) was generated by primer 826 , and less number of bands (two bands) by primer 846 . Only one primer (808) generated monomorpic bands. The polymorphic bands were exhibited by twelve primers, and out of these five primers $(843,853$, $813,829,846)$ generated an amplification product in

Table 1 - Characteristics of fragments amplified. Number of monomorphic, polymorphic and genotype-specific loci generated in the reaction with RAPD and ISSR primers for control and putative mutants of Petunia $\times$ atkinsiana D. Don, containing different EMS and NaCl treatments.

\begin{tabular}{|c|c|c|c|c|c|c|c|c|c|c|c|}
\hline \multirow{2}{*}{ Technique } & \multirow{2}{*}{ Primer No. } & \multirow{2}{*}{$\begin{array}{l}\text { Fragment } \\
\text { size range } \\
\quad(b p)\end{array}$} & \multicolumn{3}{|c|}{-----------------------Loci---------------------- } & \multicolumn{5}{|c|}{ 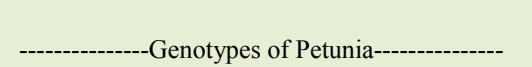 } & \multirow{2}{*}{$\begin{array}{c}\text { Total } \\
\text { generated } \\
\text { amplicons }\end{array}$} \\
\hline & & & Monomorphic & Polymorphic & $\begin{array}{l}\text { Genotype- } \\
\text { Specific }\end{array}$ & Control & Mutant & $\begin{array}{c}\text { Mutant } \\
50 \mathrm{mM} \\
\mathrm{NaCl}\end{array}$ & $\begin{array}{c}\text { Mutant + } \\
100 \mathrm{mM} \\
\mathrm{NaCl}\end{array}$ & $\begin{array}{c}\text { Mutant + } \\
150 \mathrm{mM} \\
\mathrm{NaCl}\end{array}$ & \\
\hline RAPD & $\begin{array}{c}\text { pr176, pr269, } \\
\text { pr429, } \operatorname{pr} 447, \\
\text { pr539, } \\
\text { pr29, pr66, } \\
\text { pr88, pr99, } \\
\text { pr107, pr139, } \\
\text { pr310, pr797, } \\
\text { pr815, pr879, } \\
\text { pr875, pr144, } \\
\text { pr611, } \\
\text { pr1100, } \\
\operatorname{pr} 110, \operatorname{pr} 483, \\
\operatorname{pr} 519, \operatorname{pr} 920, \\
\operatorname{pr} 1049\end{array}$ & 1820-380 & $320 / 64(65 \%)$ & $133 / 41(28 \%)$ & $9 / 9(2 \%)$ & 69 & 79 & 104 & 101 & 109 & $462 / 114$ \\
\hline ISSR & $\begin{array}{c}859,843, \\
810,819, \\
853,849, \\
840,808, \\
813,823, \\
826,829, \\
846\end{array}$ & $1560-410$ & $115 / 23(45 \%)$ & $121 / 38(51 \%)$ & $3 / 3(1 \%)$ & 25 & 32 & 60 & 60 & 62 & $239 / 64$ \\
\hline
\end{tabular}

Ciência Rural, v.48, n.12, 2018. 
Table 2 - Specific products from RAPD and ISSR primers for EMS induced putative mutants, putative mutants tested for salt tolerance medium (MS supplemented with 50,100 and 150mM NaCl) and for control.

\begin{tabular}{|c|c|c|}
\hline & Technique & Primers and length size (bp) \\
\hline \multirow{2}{*}{$\begin{array}{l}\text { Putative mutants tested for } \\
\text { salt tolerance medium }\end{array}$} & RAPD & 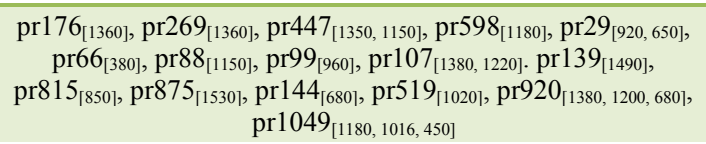 \\
\hline & ISSR & $\begin{array}{c}859_{[1120]}, 843_{[1180,950,620]}, 810_{[930]}, 819_{[1420,1380]}, 853_{[1420,1300,1180} \\
1050], 849_{[1540,1380,1180,920,410]}, 840_{[880,620]}, 813_{[1520,1200,980,420]} \\
826_{[1380]}, 829_{[1400,580,510]}, 846_{[1560,780]}\end{array}$ \\
\hline Putative mutants & \multirow{2}{*}{ RAPD } & $\operatorname{pr} 539_{[1100,480]}, \operatorname{pr} 429_{[1820]}, \operatorname{pr} 797_{[1490]}$ \\
\hline Control & & $\operatorname{pr} 88_{[620,520]}, \operatorname{pr} 1100_{[380]}, \operatorname{pr} 1049_{[780,650]}$ \\
\hline Putative mutants & \multirow{2}{*}{ ISSR } & $819_{[1080]}, 849_{[1420]}, 823_{[460]}$ \\
\hline Control & & $823_{[1100]}$ \\
\hline
\end{tabular}

$100 \%$ of the accession tested. An intense non-control 28 specific bands in PCR reactions with eleven primers was obtained among the selected salt tolerant lines putative mutants (Table 2). Furthermore, in our experiment, we noticed that three ISSR primers $(819,849$ and 823$)$ generated one band that was characteristic of only all EMS putative mutants of Petunia (Table 2). Moreover, one genotype-specific band for control bulked sample was generated by primer 823 (Table 2).

\section{DISCUSSION}

In this study, molecular characterization was performed to detect mutation and somaclonal variation among Petunia $\times$ atkinsiana D. Don cv. Prism Red explants obtained in in vitro callus culture. We used two types of molecular techniques to amplify different genomic regions of Petunia: RAPD and ISSR. Many authors (LAKSHMANAN et al., 2007; MIRI et al., 2009; SHALABY \& ELBANNA, 2013; FAROKHZADEH \& ALIFAKHERI, 2014) have indicated that these techniques, based on PCR reaction are a powerful and reliable tool in genetic studies for improvement in tolerance to environmental stresses in many crop plants. These techniques are a simple starting point for comparative analysis and screening that indicate the loci directly related to the observed variability. However, genotyping a large population using these technique is time-consuming and expensive. QUARRIE et al. (1999) have suggested grouping of plants according to the expression of a particular trait and extracting DNA from these bulks. BSA has been successfully used to rapidly identify markers linked to any specific locus with different traits, such as changes in Coffea arabica explants regenerated by indirect and direct somatic embryogenesis (SANCHEZTEYER et al., 2003), sex in jojoba (SHARMA et al., 2008), resistance to pre-harvest sprouting in rye (MASOJĆ et al., 2009), and DNA markers linked to salt tolerance traits in wheat (BHUTTA \& HANIF, 2013), indicating their wide use in genetic analysis. Differences in results obtained from various studies on levels of polymorphism can be attributed to differences among the genotypes chosen for the studies. However, polymorphisms usually result in the presence or absence of an amplification product from a single locus. The presence of products that can be polymorphic can be useful as genetic markers. When markers linked to traits of interest are available, a marker-assisted selection can be performed. For this purpose, highly saturated linkage maps can provide a choice of markers closely linked to a specific trait (MUNNS, 2005).

BSA using RAPD and ISSR markers in this study provided information on genetic diversity caused by environmental stress factor such as chemical mutagen (EMS) or salt $(\mathrm{NaCl})$ in Petunia $\times$ atkinsiana $\mathrm{D}$. Don cv. Prism Red in in vitro callus culture. We performed molecular analysis by assuming the selection of genetic markers that may differentiate the control sample and four bulked samples of the plants treated with the chemical mutagen with an indication of their correlation with the trait - increased tolerance to salinity. After analyzing the results of molecular markers' segregation, 133 RAPD and 121 ISSR polymorphic loci were selected. Furthermore, analysis of electrophoregrams revealed two patterns in segregation of molecular markers within the 
examined bulked groups. The first pattern pointed to the differences between the plants' constituting control (non-mutated) and putative mutants and was observed in all variants treated with EMS. The use of RAPD markers for the genetic analysis allowed to obtain $17 \%$ of the differentiating products and $14 \%$ ISSR markers. Such strong bidirectional effect of the disruptive selection on the segregation of alleles was detected for six RAPD markers (pr539, pr429, pr797, pr88, pr1100, pr1049) and for three ISSR markers $(819,849,823)$. Thus, it can be concluded from electrophoretic separation images that the use of a chemical mutagen (EMS) caused numerous mutation in the Petunia genome, and the number of identified markers differentiating the examined samples indicates their dispersal throughout the entire genome of the analyzed species.

The second pattern was observed within the putative mutants. The polymorphism of markers involved an existence in the presence or absence of bands between the putative mutants tested on MS media with different concentrations of salt $(\mathrm{NaCl})$ and putative mutants propagated on MS media with no salt addition. We observed $22 \%$ of this kind of pattern of distorted segregation that was characteristic for sixteen RAPD markers (pr176, pr269, pr447, pr598, pr29, pr66, pr88, pr99, pr107, pr139, pr815, pr875, pr144, pr519, pr920, pr1049) and 44\% for eleven ISSR markers $(859,843,810,819,853,849,840,813,826$, $829,846)$. This type of segregation thus indicates the presence of an additional genetic variability caused by abiotic stress factor, which is salinity.

Low genetic diversity observed in our study may be because the genomic regions conferred to EMS and $\mathrm{NaCl}$ salt stress were tagged; this is because the primers generated polymorphism between non-mutants, putative mutants and putative mutants tested for salt tolerance in bulked DNAs used to characterize these 12 genotypes.

Identification of many genetic markers that differentiate the examined bulked samples confirms that the occurrence of increased tolerance to salinity as a stressor is controlled by many differentiating loci located on many sites in the genome. This confirms that many different genes and interactions between them control this trait.

According to YOKOI et al. (2002) it is possible to transfer a single gene in a plant to increase its tolerance by many folds. However, inter- or intra-species hybridization induces mutations or somaclonal variation in cell and tissue cultures to produce a salt-tolerant cultivar is very slow with limited success. The literature on obtaining a new variety with an increased tolerance through conventional breeding approach is scarce (TAHIRA et al., 2006). Traditional approaches are limited by the complexity of stress tolerance traits, low genetic variation and field components under stress, and lack of efficient selection techniques (BHUTTA \& HANIF, 2013; HADI \& FULLER, 2013). Moreover, it happens that the resistance to salt stress is subject to changes during plant growth. Therefore, conventional breeding programs can be more productive if they are integrated with newer technologies of plant molecular biology.

\section{CONCLUSION}

Our study detected two RAPD and ISSR markers significantly associated with changes induced by chemical mutagenesis and salt stress factor $(\mathrm{NaCl})$. Till date, there are few scientific reports on the use of BSA method to determine genetic variability between the putative mutants obtained in in vitro culture or putative mutants characterized by an increased tolerance to environmental stress. Indication of molecular markers that differentiate the analyzed bulked group is just a starting point to verify the usefulness of these markers in the selection work on a broader genetic material. Hence, an attempt to identify the marker loci determining the observed variability of the trait was undertaken. Results of research confirmed the hypothesis that part of the marker loci within which genetic changes were noted, with the participation of chemical agent or stressor, will be differentiating (polymorphic loci) in the analyzed pooled groups. These preliminary investigations using BSA method could be useful in marker-assisted breeding programs that can be used as a candidate marker for further gene mapping.

Use of RAPD and ISSR markers in this study has given newer opportunities for plant biologists to study the relationship between traits and their genetic control. The BSA is a valuable alternative approach that overcomes the necessity to genotype every member of a population. BSA allows a faster validation of molecular markers for an identification of genotypes with differentiated allele frequency between the lines selected for the examined trait. In this study, we have shown that BSA coupled with physiological studies can help to identify traits important in determining salt stress resistance in Petunia $\times$ atkinsiana D. Don cv. Prism Red and provide molecular markers for this trait. The BSA should be a valuable aid for plant biologists in the future. These results suggest the importance 
of studying the salt response of ornamental potted plants to help the growers and gardeners to select the species, which are more tolerant to salt stress.

\section{DECLARATION OF CONFLICTING INTERESTS}

The authors declare no conflict of interest. The founding sponsors had no role in the design of the study; in the collection, analyses, or interpretation of data; in the writing of the manuscript, and in the decision to publish the results.

\section{ACKNOWLEDGEMENTS}

This work was supported by the West Pomeranian University of Technology of grants nr 518-07-017-3171-01/18.

\section{AUTHORS' CONTRIBUTIONS}

MKM conceived and designed experiments. MKM and $\mathrm{AB}$ performed the experiments and carried out the lab analyses. MKM prepared the draft of the manuscript. All authors critically revised the manuscript and approved of the final version.

\section{REFERENCES}

BAGHWAT, B. DUNCAN, E.J. Mutation breeding of banana cv. Highgate(Musa spp.,AAAGroup) fortoleranceto Fusarium oxysporum f. sp. cubense using chemicals mutagens. Science Horticulture, v.73, p.11-22, 1998. Available from: <www.sciencedirect.com/science/ article/pii/S0304423897001416?via\%3Dihub>. Accessed: Jan. 06, 2010. doi:10.1016/S0304-4238(97)00141-6.

BAIRU, M.W. et al. Somaclonal variation in plants: causes and detection methods. Plant Growth Regulators, v.63, p.147-173, 2011. Available from: <https://ink.springer.com/article/10.1007/ s10725-010-9554-x>. Accessed: Jul 06, 2017. doi:10.1007/s10725010-9554-x.

BIDABADI, S.S. et al. Evaluation of in vitro water stress tolerance among EMS - induced variants of banana (Musa spp., AAA), using morphological, physiological and molecular traits. Journal of Crop Science and Biotechnology, v.14, p.255-263, 2011. Available from: $<$ https://link.springer.com/article/10.1007/s12892-011-0073-8>. Accessed: Jan. 05, 2012. doi: 10.1007/s12892-011-0073-8.

BERENSCHOT,A.S. et al. Mutagenesis in Petunia $\times$ hybrida Vilm. and isolation of a novel morphological mutant. Brazilian Journal of Plant Physiology, v. 20, p.16-27, 2008. Available from: <http://www.scielo. $\mathrm{br} /$ scielo.php?pid=S1677-04202008000200002\&script=sci_arttext $>$. Accessed: Jan. 05, 2012. doi:10.1590/S1677-04202008000200002.

BHUTTA, W.M.; HANIF, M. Identification of RAPD markers linked to salinity tolerance in wheat. African Journal of Biotechnology, v.12, p.2175-2181, 2013. Available from: <http://www.academicjournals. org/AJB>. Accessed: Jul. 05, 2017. doi: 10.5897/AJB09.973.

FAROKHZADEH, S.; ALIFAKHERI, B. Marker-assisted selection for disease resistance:applications in breeding (Review). International Journal of Agriculture and Crop Science. IJACS/2014/7-14/1392-1405, 2014.
FULLER, M.P. et al. Evaluation of abiotic stress resistance in mutated populations of cauliflower (Brassica oleracea ver. botrytis). Plant Cell Tissue Organ Culture, v.86, p.239-248, 2006. Available from: <https://link.springer.com/article/10.1007/s11240-006-91124>. Accessed: Jul. 05, 2017. doi:10.1007/s11240-006-9112-4.

GOPAL, J.; IWAMA, K. In vitro screening of potato against water stress mediated through sorbitol and polyethylene glycol. Plant Cell Reports, v.26, p.693-700, 2007. Available from: <https://link. springer.com/article/10.1007/s00299-006-0275-6>. Accessed: Jul. 05, 2017. doi: 10.1007/s00299-006-0275-6.

HADI, F.; FULLER, M.P. Chemically induced mutants of Brassica oleracea var. botrytis maintained stable resistance to drought and salt stress after regeneration and micropropagation. American Journal of Plant Science, v.4, p.498-507, 2013. Available from: $<$ http://www.scirp.org/journal/ajps>. Accessed: Jul. 06, 2017. doi:10.4236/ajps.2013.

JAIN, S.M. Tissue culture induced variation in crop improvement. Euphytica, v.118, p.153-166, 2000. Available from: <https://link. springer.com/content/pdf/10.1023\%2FA\%3A1004124519479. pdf>. Accessed: Jul. 05, 2017.

KRUPA-MAŁKIEWICZ, M. et al. Induced mutations through EMS treatment and in vitro screening for salt tolerance plant of Petunia $\times$ atkinsiana D. Don. Notulae Botanicae Horti Agrobotanici Cluj-Napoca, v.45(1), p.190-196, 2017. Available from: <http:// www.notulaebotanicae.ro/index.php/nbha/article/view/10578>. Accessed: Jul. 05, 2017. doi: 10.15835/nbha45110578.

LAKSHMANAN, V. et al. Molecular analysis of genetic stability in long-term micropropagated shoots of banana using RAPD and ISSR markers. Electronic Journal of Biotechnology, 10(1). doi:10.2225/vol10-issue1-fulltex-12, 2007.

LUAN, Y-S. et al. Mutation induced by ethylmethanesulphonate (EMS), in vitro screening for salt tolerance and plant regeneration of sweet potato (Ipomoea batatas L.). Plant Cell Tissue Organ Culture, v. 88 , p. 77-81, 2007. Available from: <https://link. springer.com/article/10.1007/s11240-006-9183-2>. Accessed: Jul. 05, 2017. doi: 10.1007/s11240-006-9183-2.

MASOJĆ, P. et al. Three classes of loci controlling preharvest sprouting in rye (Secale cereale $\mathrm{L}$.) discerned by means of bidirectional selective genotyping (BSG). Euphytica, v. 170, p.123-129, 2009. Available from: <https://link.springer.com/article/10.1007/s10681-009-99521>. Accessed: Jul. 05, 2017. doi:10.1007/s10681-009-9952-1.

MIRI, S.M. et al. Analysis of induced mutants of salinity resistant banana (Musa acuminate cv. Dwarf Cavendish) using morphological and molecular makers. Iranian Journal of Biotechnology, v.7, p.86-92, 2009. Available from: <http://www. ijbiotech.com/article_7086_0.html>. Accessed: Jul. 05, 2017.

MIRI, S.M. et al. Molecular analysis of Musa mutants resistant to salinity by microsatellite markers. Trakia Journal of Sciences, v.2, p.114-120, 2014. Available from: <http://www. uni-sz.bg/tsj/Vol.\%2012,\%20N2,\%202014/S.M.Miri.pdf>. Accessed: Jul. 05, 2017.

MUNNS, R. Genes and salt tolerance: bringing them together. New Phytologist, v.167, p.645-663, 2005. Available from: $<$ https://nph. onlinelibrary.wiley.com/doi/full/10.1111/j.1469-8137.2005.01487. $\mathrm{x}>$. Accessed: Jul. 05, 2017. doi:10.1111/j.1469-8137.2005.01487.x. 
PATADE, V.Y. et al. Molecular profiling using RAPD technique of salt and drought tolerant regenerants of Sugarcane. Sugar Technology, v.8, p.63-68, 2006. Available from: <https://link. springer.com/content/pdf/10.1007\%2FBF02943744.pdf $>$. Accessed: Sept. 05, 2017.

QUARRIE, S.A. et al. Bulk segregant analysis with molecular markers and its use for improving drought resistance in maize. Journal of Experymental Botany, v.50, p.1299-1306, 1999. Available from: <https://watermark.silverchair.com/50-337-1299. pdf $>$. Accessed: Jul. 05, 2017.

SANCHEZ-TEYER, F. et al. Culture-induced variation in plants of Coffea arabica cv. Caturra rojo, regenerated by direct and indirect somatic embryogenesis. Molecular Biotechnology, v.23, p.107115, 2003. Available from: <https://link.springer.com/content/ pdf/10.1385/MB:23:2:107.pdf>. Accessed: Jul. 05, 2017.

SHARMA, K. et al. ISSR marker-assisted selection of male and female plants in a promising dioecious crop: jojoba (Simmondsia chinensis). Plant Biotechnology Reports, v.2, p.239-243, 2008. Available from: $<$ https://link.springer.com/article/10.1007/s11816-008-0070-7> Accessed: Jul. 05, 2017. doi:10.1007/s11816-008-0070-7.

SHALABY, T.A.; EL-BANNA, A. Molecular and horticultural characteristics of in vitro induced tomato mutants. Journal of Agricultural Science, v.5, p.155-163, 2013. Available from: <https://
www.researchgate.net/profile/Tarek_Shalaby3/publication/257045255>. Accessed: Jul. 05, 2017. doi: 10.5539/jas.v5n10p155.

TAHIRA, W.M. et al. Inheritance of salt tolerance as measured via root length in spring wheat (Triticum aestivum L.) under different salinity levels. Journal of Crop Improvement, v.16, p.131-139, 2006. Available from: <https://www.tandfonline. com/doi/abs/10.1300/J411v16n01_09>. Accessed: Jul. 05, 2017. doi:10.1300/J411v16n01_09.

VANDENBUSSCHE, M. et al. Petunia, your next supermodel?. Frontiers in Plant Science, v.7, 72, 2006. Available from: $<$ https://www.frontiersin.org/articles/10.3389/fpls.2016.00072/>. Accessed: Jun. 04, 2017. doi: 10.3389fpls.2016.00072.

WILLIAMS, J.G.K. et al. DNA polymorphisms amplifies by arbitrary primers are useful as genetic markers. Nuclear Acids Research, v.18, p.6531-6535, 1990. Available from: <https:// academic.oup.com/nar/article-abstract/18/22/6531/1054266?r edirectedFrom $=$ PDF $>$. Accessed: Jun. 04, 2017. doi: 10.1093/ nar/18.22.6531.

YOKOI, S. et al.; Salt stress tolerance of plants. Japan International Research Centre of Agricultural Sciences Working Report, p.25-33, 2002. Available from: <http://www. plantstress.com/Articles/salinity m/salinity $m$ files/JIRCAS. pdf>. Accessed: Jun. 04, 2017. 